\title{
INCREASING SOCIAL RESPONSIBILITY IN THE MANAGEMENT OF INDUSTRIAL ENTERPRISES (USING THE EXAMPLE OF “ARTERIUM” CORPORATION)
}

\author{
Vladyslav Protsenko \\ Zaporizhzhia National University \\ Zaporizhzhia, Ukraine \\ ORCID: 0000-0003-1509-7522
}

\author{
Oleksandr Oliinyk \\ Zaporizhzhia National University \\ Zaporizhzhia, Ukraine \\ ORCID: 0000-0003-0511-7681
}

*Corresponding author email: a.n.oleynick@gmail.com

\begin{abstract}
The purpose of the study is to identify the ways to increase social responsibility in the modern management of industrial enterprises on the example of corporation "Arterium". The basic principles that have been used in the research are historical, systematic and comparative methods, institutional and structural-functional approaches. In the paper the theoretical foundations of corporate social responsibility were considered, foreign and domestic practices were analyzed, in particular, based on "Arterium" corporation. The urgency of the work is to study the current state of corporate social responsibility in Ukraine, and, in particular, at the "Arterium" enterprise. More and more companies are introducing CSR into their business, business standards are changing, and socially responsible behavior becomes an essential element of successful entrepreneurship. It was found that the corporation, implementing the principles of social responsibility of business towards society, focuses on the following areas: business ethics and ethical marketing, innovation and product development, patient health and safety, protection against fraud, investment in employee training, environmental policy and Green office, support for health, sports and education programs, community care.

According to the results of the conducted research:

- the situation and effectiveness of corporate social responsibility at the specified enterprise have been substantiated;

- the algorithm for developing a social report for "Arterium" corporation has been proposed as a method of increasing social responsibility.

To achieve the goal, the following tasks have been solved:

- the essence of the concept of corporate social responsibility and the state of CSR in the world have been investigated;

- the activity of "Arterium" corporation has been analyzed;

- the state of corporate social responsibility in Ukraine has been assessed;

- the experience of foreign companies in the field has been studied.
\end{abstract}

Keywords: corporate social responsibility, social reporting, social control, social investment. JEL Classification: M11, M14, M31. 
Protsenko, V. and Oliinyk, O. (2019). "Increasing social responsibility in the management of industrial enterprises (using the example of "Arterium" corporation)", Management and entrepreneurship: trends of development, 3(09), pp. 52-65. DOI: https://doi.org/10.26661/2522-1566/2019-3/09-04

\section{INTRODUCTION}

The current state of development of society is characterized by complexity, inconsistency and ambiguity, due to a number of factors of subjective and objective nature. The effectiveness of the reform processes largely depends on the existence of an effective mechanism of public regulation. It is confirmed that any project has greater chances to succeed provided that it has quality scientifically grounded support. The current situation determines the need for scientific understanding of the complex problems in the field of social responsibility.

Social responsibility is an integral element in the macro-system "state-society-person". Effective social control is one of the first signs of an independent democratic social state of civil society. Through the implementation of a set of actions aimed at increasing the level of social responsibility of industrial enterprises, it is possible to improve the situation in the social, economic, political and other spheres. However, at this stage of development, the implementation of this set of actions is not possible for a number of reasons.

The problem of implementation of corporate social responsibility in industrial enterprises is its multifaceted character. Attention to corporate social responsibility in Ukraine has recently emerged. Due to this fact, analysts and scientists do not have a unified approach to understanding the problem.

\section{LITERATURE REVIEW}

The term "corporate social responsibility" (hereafter CSR) is considered by such foreign researchers: Thomas Bredgaard (2004), Howard Bowen (2013), Jeremy Moon (2014), Milton Friedman (1970), Philip Kotler (2005), Peter Drucker (1993) and many others.

Own vision of corporate social responsibility in Ukraine has recently begun to form. The following scholars worked on the study of CSR: G. Popovich, F. Evdokimov, G. Nazarov, O. Filipchenko, Yu. Saenko, O. Osinkina and others.

\section{METHODOLOGY}

The acceptance of social responsibility is entirely voluntary. It can depend only on the desire of the company to contribute to the development of society. Social responsibility is aimed at streamlining, harmonizing social relations and ensuring their progressive and stable development. Social responsibility ensures social and personal security, maintains and strengthens social harmony, the integrity of society and the state. Social security, therefore, objectively requires a reliable mechanism of social responsibility (V. Hryshchuk, 2012).

Social responsibility is the responsibility of the management of the organization to make decisions and carry out actions that increase the level of well-being.

In recent years, the institute of corporate social responsibility (CSR) has gone from the organizational and managerial exoticism of global corporations to standard technologies for the introduction of this phenomenon into the practice of organizations of various forms of ownership and management, of various sizes and types of economic activities operating around the world (A. Kolot, 2018). Moreover the methodology for assessing the effectiveness of socially responsible activities of the enterprise has been recently created. This method is aimed at determining the effectiveness of social investments of the enterprise by calculating quantitative and qualitative indicators (Table 1). 


\section{Methods of quantitative and qualitative assessment of CSR of the enterprise}

\begin{tabular}{|c|c|}
\hline Quantitative indicators & Quality indicator \\
\hline $\begin{array}{l}\text { The index of specific social investments (IL) - represents } \\
\text { the value of social investments of the surveyed } \\
\text { companies per employee (in monetary units): }\end{array}$ & $\begin{array}{l}\text { The qualitative index of social investments for the i-th } \\
\text { enterprise ( IKi ) shows the level of complexity of social } \\
\text { activity of the enterprise, \%: }\end{array}$ \\
\hline $\mathrm{IL}=\frac{\sum_{\mathrm{i}=1}^{\mathrm{n}} \mathrm{Ci}}{\sum_{\mathrm{i}=1}^{\mathrm{n}} \mathrm{Li}} \times 100 \%$ & $\mathrm{IKi}=\left(\frac{1}{\mathrm{~m}} \sum_{\mathrm{i}=1}^{\mathrm{m}} \mathrm{Xij}\right) \times 100 \%$ \\
\hline $\begin{array}{l}\text { where } \mathrm{C} i \text { is the volume of social investment of the } \mathrm{I}-\text { th } \\
\text { company (including voluntary and mandatory costs of } \\
\text { social programs); Li is the average number of employees } \\
\text { of the } \mathrm{i} \text {-th company; } \mathrm{n} \text { is the number of companies } \\
\text { participating in the survey. }\end{array}$ & $\begin{array}{l}\text { where } \mathrm{Xij} \text { is a Boolean variable that takes the value } 1 \text { if } \mathrm{j} \text { - } \\
\text { a sign takes place in the } \mathrm{i} \text { - th company, and is equal to } 0 \text { if } \\
\text { the sign is absent; } \mathrm{m} \text { is the number of signs by which the } \\
\text { social activity of the company is evaluated, participates in } \\
\text { the study. }\end{array}$ \\
\hline $\begin{array}{l}\text { The share of social investments of the surveyed } \\
\text { companies in their total sales ( IS) is measured as a } \\
\text { percentage }\end{array}$ & $\begin{array}{l}\text { The qualitative index of social investments for the } \mathrm{j}-\text { th } \\
\text { trait (IKj) shows the degree of presence of this qualitative } \\
\text { trait in the statistical voters of the enterprise, } \% \text { : }\end{array}$ \\
\hline$: I S=\frac{\sum_{i=1}^{\mathrm{n}} \mathrm{Ci}}{\sum_{i=1}^{n} \mathrm{Si}} \times 100 \%$ & $I K j=\left(\frac{1}{n} \sum_{j=1}^{n} X i j\right) \times 100 \%$ \\
\hline where S1 1 & $\begin{array}{l}\text { where } \mathrm{n} \text { is the number of companies participating in the } \\
\text { study. }\end{array}$ \\
\hline $\begin{array}{l}\text { The share of social investments of surveyed companies } \\
\text { in the total amount of their profits before taxation (IP), } \\
\text { which is measured as a percentage: }\end{array}$ & $\begin{array}{l}\text { The general qualitative index of social investments (IK) } \\
\text { shows the level of complexity of the social activity of the } \\
\text { enterprise, \%: }\end{array}$ \\
\hline $\mathrm{IP}=\frac{\sum_{\mathrm{i}=1}^{\mathrm{n}} \mathrm{Ci}}{\sum_{i=1}^{n} \mathrm{Pi}} \times 100 \%$ & $\left.\mathrm{IK}=\left(\frac{1}{\mathrm{n} \times \mathrm{m}}\right) \sum_{i=1}^{\mathrm{n}} \sum_{i=1}^{\mathrm{m}} \mathrm{Xij}\right) \times 100 \%$ \\
\hline $\begin{array}{l}\text { where } \mathrm{P} i \text { - the amount of profits before taxation of the } \mathrm{i}- \\
\text { th company. }\end{array}$ & \\
\hline
\end{tabular}

Source: compiled based on “Arterium” Corporate Social Responsibility Report (2013).

\section{RESULTS AND DISCUSSION}

The term "corporate social responsibility" is widely used by general public due to the fact that it more accurately reflects the modern approach to socially responsible behavior of business organizations. The interpretation of social responsibility as a corporate one is justified by a number of factors:

1. Leading corporations have shown commitment to socially responsible behavior and social activity in its broadest sense.

2. The corporation is the leading and most complex organizational form of doing business.

3. The focus on the corporation does not deny the focus on any other structures that embody business and managers formulating organizational (corporate) policies and their constituents; it gives grounds for talking about the adoption of organizational (corporate) citizenship.

Corporate social responsibility is divided into internal and external (Table 2). 
Protsenko, V. and Oliinyk, O. (2019). "Increasing social responsibility in the management of industrial enterprises (using the example of "Arterium" corporation)", Management and entrepreneurship: trends of development, 3(09), pp. 52-65. DOI: https://doi.org/10.26661/2522-1566/2019-3/09-04

\section{Social Responsibility Groups}

\begin{tabular}{|l|l|}
\hline \multicolumn{1}{|c|}{ Internal social responsibility } & \multicolumn{1}{c|}{ External social responsibility } \\
\hline 1. Medical and social insurance & 1. Sponsorship and corporate charity \\
\hline 2. Stability of compensation system & 2. Environmental protection \\
\hline 3. Safety of work & 3. Interaction with local authorities \\
\hline 4. Development of human resources (training programs) & 4. Participation in crisis situations \\
\cline { 2 - 2 } & 5. Responsibility to consumers \\
\hline
\end{tabular}

\section{Source: compiled based on T. Antoshko et al (2013).}

Principles of Corporate Social Responsibility are a new system for improving the competitiveness of enterprises, which requires the establishment of close links between inter-branch corporate associations and representatives of the state and society. Implementation of the principles of corporate social responsibility will reduce costs, operational risks, increase revenues, stimulate innovation, facilitate access to commodity markets and capital markets, improve reputation, etc. (Y. Behma et al, 2006).

The choice of following corporate social responsibility policies is strategically important. Thus, corporate social responsibility as a policy and the concept of strategic development of an enterprise implies: formation and strengthening of image and business reputation; corporate development (restructuring and organizational changes involving representatives of senior management of enterprises, their staff and public organizations); ecological policy and use of natural resources; management of personnel development; health, safety and health, and respect for human rights; interaction with local authorities, state structures and public organizations for solving common social problems, etc. (A. Kolot, 2018).

When analyzing foreign enterprises, it can be concluded that corporate social responsibility plays an important role in the formation of efficient economy, because it is based on the use of CSR standards. Table 3 shows companies that use CSR principles in their activities.

Table 3

Corporations of foreign countries that use the principles of CSR

\begin{tabular}{|l|l|l|}
\hline \multicolumn{1}{|c|}{ Country } & \multicolumn{1}{|c|}{ Company } & \multicolumn{1}{c|}{ CSR Standards } \\
\hline \multicolumn{1}{|c|}{1} & \multicolumn{1}{|c|}{3} \\
\hline France & Citroën & $\begin{array}{l}\text { France Citroën Dow Jones Sustainability Index, FTSE4Good Indices, EMAS } \\
\text { System, AA1000 Standard, European Union Eco-Label }\end{array}$ \\
\hline Brazil & Petroleo & $\begin{array}{l}\text { Brasileiro S.A. FTSE4Good Indices, ISO9000 / ISO14000 Standards, } \\
\text { AA1000 Standard }\end{array}$ \\
\hline Australia & Orica & $\begin{array}{l}\text { Code of Business Conduct of APEC Countries, FTSE4Good Indices, } \\
\text { ISO9000 / ISO14000 Standards, AA1000 Standard, European Union } \\
\text { EcoLebel }\end{array}$ \\
\hline Denmark & British & $\begin{array}{l}\text { Dow Jones Sustainability Index, FTSE4Good Indices, EMAS System, } \\
\text { AA1000 Standard, European Union Eco-Label }\end{array}$ \\
\hline & FL Smidth & $\begin{array}{l}\text { Dow Jones Sustainability Index, FTSE4Good Indices, ISO9000 / ISO14000 } \\
\text { Standards, AA1000 Standard, Ethical Trade Initiative, Eco-Label of the } \\
\text { European Union }\end{array}$ \\
\hline
\end{tabular}

Table 3 continuation on the next page 
Table 3 continuation

\begin{tabular}{|l|l|l|}
\hline \multicolumn{1}{|c|}{1} & \multicolumn{1}{|c|}{2} & \multicolumn{1}{c|}{3} \\
\hline India & $\begin{array}{l}\text { Reliance } \\
\text { Industries }\end{array}$ & FTSE4Good Indices, ISO9000 / ISO14000 Standards, AA1000 Standard \\
\hline Spain & $\begin{array}{l}\text { Maquinaria } \\
\text { GEKA S. A. }\end{array}$ & $\begin{array}{l}\text { FTSE4Good Indices, EMAS System, AA1000 Standard, European Union } \\
\text { Eco-Label }\end{array}$ \\
\hline Italy & $\begin{array}{l}\text { Impregilo } \\
\text { S.p.A. }\end{array}$ & $\begin{array}{l}\text { FTSE4Good Indices, EMAS System, AA1000 Standard, European Union } \\
\text { Eco-Label }\end{array}$ \\
\hline Germany & Henschel & $\begin{array}{l}\text { Dow Jones Sustainability Index, FTSE4Good Indices, EMAS System, } \\
\text { AA1000 Standard, European Union Eco-Label }\end{array}$ \\
\hline Japan & $\begin{array}{l}\text { Yamaha Motor } \\
\text { Company } \\
\text { Limited }\end{array}$ & FTSE4Good Indices, EMAS System, AA1000 Standard Sustainability Index, \\
\hline
\end{tabular}

Source: compiled based on N. Tkachenko (2008).

The main benefits and incentives of Ukrainian companies following CSR are:

- increase in profits, increase of company growth rates;

- the opportunity to access socially responsible investments, distributing which investors take into account the indicators characterizing the company's social and ethical spheres in the field of environmental protection (FTSE4Good, Dow Jones Sustainable Index);

- possible reduction of operating costs, for example, by reducing waste from production or processing, increasing the efficiency of the use of electricity or selling recycled materials;

- improvement of the reputation causing further opportunities for developing, entering new markets and opening new business directions;

- sales growth, increase of customers' loyalty;

- increase of labor productivity;

- increase of competitiveness of the company as a whole.

One of the corporations that use CSR is "Arterium" corporation. The Ukrainian pharmaceutical company "Arterium" works in a sphere that values human health and life most of all, and this business is united by more than two thousand employees. Social responsibility is an important and complex concept for the company. Using this term implies the responsibility of all the groups and target audiences affected by the activities of this corporation. The corporation seeks to establish a harmonious, trusting and long-term relationship with all of them.

The corporation is aware of the importance of social, regulatory and environmental issues and the harmonious existence of all organizations and individuals with whom the company interacts. The corporation is a powerful Ukrainian pharmaceutical manufacturer and seeks to bring as much benefit as possible to the country, its people and society as a whole.

There are still areas in need of support and assistance on the country's path to European values, and therefore the corporation devotes great attention to the revival of the charity traditions that were laid down by the founders of the "Arterium" corporation. Within the framework of charitable activities a program of assistance to local communities is being implemented at the locations of corporation enterprises - Kyiv and Lviv.

Major efforts in the area of social responsibility focus on such important areas as ethics, products, employees, the environment and society. "Arterium" company defines these areas as key in its activities.

Consider the key areas of the "Arterium" corporation in more detail:

1. Ethics: clinical research and business ethics (ethical marketing).

Clinical trials are critical to determining the safety and effectiveness of new drugs. Patient safety for a company is a key issue at the stage of pharmaceutical development. 
Protsenko, V. and Oliinyk, O. (2019). "Increasing social responsibility in the management of industrial enterprises (using the example of "Arterium" corporation)", Management and entrepreneurship: trends of development, 3(09), pp. 52-65. DOI: https://doi.org/10.26661/2522-1566/2019-3/09-04

"Arterium" carries out clinical trials in accordance with: GCP standards (proper clinical practice is an international standard of ethics and quality of scientific research that describes the rules for designing, conducting, maintaining documentation and reporting on research involving human being as a subject) and GLP (due laboratory practice - a system of norms, rules and guidelines aimed at ensuring the consistency and reliability of laboratory research results), the order of the Ministry of Health of Ukraine "Procedure for conducting clinical trials of medicine tools and examination of materials of clinical trials", instructions "Medicines. Good clinical practice", approved by the order of the Ministry of Health of Ukraine, legislation of the countries in which "Arterium" carries out clinical research.

In conducting preclinical studies "Arterium" adheres to the norms and requirements of such documents: the order of the Ministry of Health of Ukraine "On approval of the procedure for preclinical study of medicinal products and examination of materials for pre-clinical study of medicinal products", the European Convention for the Protection of Vertebrate Animals used in experiments or in other scientific goals. The company conducts research in Ukraine, Russia and Belarus. All employees of the company involved in the process of organizing clinical trials are regularly trained in compliance with international standards and regulations. "Arterium" is a member of the Association of Clinical Research Organizations (Russia). The corporation seeks to comply with high ethical standards and compliance with all local, national laws and international norms of the countries where it conducts its business. "Arterium" operates ethically and responsibly in all spheres of activity: from research and development to production and marketing. Compliance with the rules of ethics with regard to employees, patients, clients, suppliers and other stakeholders is one of the main approaches to corporate responsibility in "Arterium" corporation.

Business ethics: the principles of ethics of business relationships of employees. This document establishes the standards of relationship between the company, its employees and partners. The ethical principles serve as the basis for the adoption of daily decisions and help maintain the reputation of an honest and reliable partner. From the employees, the company expects the observance of ethical standards in all aspects of its work, the performance of its work honestly and conscientiously, in compliance with the principles of corporate responsibility, as well as the provisions of the current legislation and regulations.

Ethical Marketing: The responsible marketing activity of "Arterium" employees enables healthcare providers to receive reliable information about medicines and, thus, promote the rational use of drugs with maximum benefit to the health of patients. By cooperating with health professionals, all "Arterium" employees adhere to current laws, rules of good practice of promotion, industry codes and internal standards of the Corporation.

Transparency in business: openness and transparency are integral elements of dialogue with stakeholders and the basis of trust between the parties. "Arterium" is a big conscientious taxpayer. By replenishing in time and in full the budget, the corporation takes direct part in improving the welfare of the country, contributing to raising the standard of living of citizens.

2. Innovations and product development

To meet the needs of each patient, the corporation is constantly looking for fresh solutions to develop new drugs and improve existing ones. The development of new drugs is carried out in accordance with the concept of "Quality through Development", according to which the composition, technology and system of specification of new drugs are developed, their pre-clinical and clinical studies are carried out in accordance with the rules of GLP and GCP. In addition, for a number of medicines that have been in the company's portfolio for a long time, the development and additional clinical research in accordance with modern regulatory requirements is being planned.

The Corporation promotes the health of patients through the development and production of innovative and high-quality drugs. Due to active innovation, cooperation with leading scientists, application of advanced technologies and quality standards in production, the portfolio of products of the company is regularly replenished with new drugs. 
The health and safety of the patient is the main goal of the corporation. "Arterium" strives to provide quality at every stage of the product life cycle, from pharmaceutical product development to distribution to the end user. "Arterium" controls the safety and efficacy of the product, from the development and research of the future drug, the selection of raw materials, components, packaging, technology, registration and entry into the market and ending the termination of the release of the drug in all markets. The Corporation maintains and develops feedback from consumers on all aspects of the quality of its products to ensure effective and safe treatment or prevention of diseases. Feedback with consumers is provided through Pharmacovision, work with complaints and customer interaction.

Falsification protection: counterfeit medicines represent a danger to the consumer and can cause serious illness. The high quality of drugs, including the adequate level of protection against possible falsifications is a strategically important tasks for the corporation. "Arterium" constantly improves the methods of protection against falsification and for this creates an original, difficult to reproduce the packaging layout, as well as provides protective unique elements. These methods of protection provide more assurance that the consumer will receive a quality drug.

3. Employees

"Arterium" invests in training and development of employees and provides them with wide opportunities for professional growth. The "Arterium" corporation personnel development system covers all categories - from workers and specialists to plant management and management companies.

"Arterium" confirmed the compliance of the labor protection system at the enterprises Kyivmedpreparat and Halychpharm with the international standard OHSAS 18001: 2007. Internal communications. Corporate portal - with the help of an intranet portal employees learn and discuss corporate news, changes in procedures, use the electronic database of corporate documents, participate in contests and plan joint leisure activities. Access to the portal company also provides employees whose activities are not related to work on the computer - through so-called "infokiosks". The corporate newspaper (Pulse newspaper) is published once a quarter and provides employees with information on the major events in the company.

Corporation "Arterium" believes that employees are the basis of the successful work of each enterprise. That is why the company's management invests a lot of money in the development of employees. Specific data is shown in Table 4.

Table 4

\section{Calculation of expenses for personnel development}

\begin{tabular}{|l|c|c|}
\hline \multicolumn{1}{|c|}{ Indicator } & 2015 & 2016 \\
\hline Number of employees trained and & 2429 & 2700 \\
\hline retraining, persons & 3000000 & 3200000 \\
\hline Total expenses for training and retraining of staff, UAH & 1235,1 & 1185,20 \\
\hline
\end{tabular}

Source: compiled by the author.

As a result of the analysis, the following conclusion can be drawn: despite the increase in the cost of training and retraining of staff, the average cost per employee has decreased. It is evident that workers have become more evidenced by the rapid development of the corporation. The company managed to minimize costs per employee, leaving staff development programs as effective.

4. Ecology

The "Arterium" corporation has introduced the Environmental Policy, which sets out the commitment of the company's top management, annually updates the goals and targets for reducing 
Protsenko, V. and Oliinyk, O. (2019). "Increasing social responsibility in the management of industrial enterprises (using the example of "Arterium" corporation)", Management and entrepreneurship: trends of development, 3(09), pp. 52-65. DOI: https://doi.org/10.26661/2522-1566/2019-3/09-04

the environmental impact and evaluates the achievement of the level of environmental characteristics.

Green Office: The corporation is committed to complying with the concept of the Green Office in the company. For this purpose the company has introduced the practice of videoconferencing to reduce the number of business trips; has reduced the volume of paper consumption (due to double-sided printing); has activated "sleep mode" on all working computers; recommends that staff shut down all equipment from the network for the night; participates in ecoevents.

\section{Society}

When selecting projects for investment in the social sphere, the priority for the corporation is to support programs in the health, sports and education sectors.

Program "What to Know". In order to raise awareness of the population about the common diseases in 2012 the program "What to Know" was initiated. In cooperation with the leading healthcare professionals, an information campaign was conducted, in which the population was informed about the methods of prevention of the most common diseases.

The program of work with interns: in implementing the program of work with trainees, the corporation offers students and graduates to undergo internships in the company, the best participants being offered further cooperation. More than 10 higher educational establishments of Ukraine receive support in the form of a professional base for educational, pre-graduate and industrial practice. The corporation also helps to equip the audience in compliance with the requirements of the specialized training directions (Arterium Corporation, 2013, "Corporate Social Responsibility Report”).

The activities of "Arterium" corporation correspond to the principles of social responsibility. In the corporation there are various programs that indicate its active participation in public life and dialogue with various social groups; careful attitude to the environment, employee care and environmental environment, etc. In our opinion, corporations need to pay attention to the deepening of social responsibility of business towards partners and the wider external environment in general. Despite all of these benefits and strengths of the "Arterium" company in corporate social responsibility, there are aspects that need to be addressed.

Since "Arterium" corporation is constantly engaged in socially responsible activities, it is important to highlight the results of its activities to users. We believe it is important to focus on this, because socially responsible activities are designed specifically for the needs of users. Thus, a significant need for management is the formation of complete, reliable and operational information for the adoption of effective socio-economic decisions. In order to meet these needs, it is necessary to compile internal social reporting.

We will develop a general algorithm for compiling social reporting for "Arterium" corporation, which can be used both for compiling the internal social report and external. Figure 1 graphically depicts the algorithm.

We propose to compile a social report of voluntary form. This will allow you to display only the information that is required by the company. We recommend analyzing qualitative and quantitative metrics in the report you created. Quantitative indicators need to be calculated economically, according to generally accepted formulas, and thus it will be possible to obtain the total amount of social costs. We recommend evaluating the qualitative indicators in a binary system, analyzing all the data obtained in a comprehensive manner.

We believe that the creation of the structure of the social report involves the development of sections and sub-clauses, which will allow the user to navigate the document and find the necessary information. Quantitative and qualitative indicators call for grouping according to the sections (Figure 1).

The responsible for drafting a social report should be a senior manager who coordinates social projects. We believe that the social report should be made once a year. It is imperative to compare 
the results of the report with the previous years and plan the activity for the next year based on the data.

\begin{tabular}{|c|c|}
\hline \multicolumn{2}{|c|}{ 1. Determination of the organizational principles of social reporting } \\
\hline & $\begin{array}{l}\text { The choice of social reporting form. Define the structure of the report and select the system of } \\
\text { qualitative and quantitative indicators }\end{array}$ \\
\hline & Identification of responsible persons. Selection of subjects of compilation of social reporting \\
\hline & $\begin{array}{l}\text { Definition of terms for the accumulation of information, compilation and disclosure of social } \\
\text { reporting }\end{array}$ \\
\hline \multicolumn{2}{|c|}{ 2. Definition of methodological foundations of social reporting } \\
\hline & Creation of a social report \\
\hline & Visualize a social report for its better perceptions by stakeholders \\
\hline & Final registration and release of the report \\
\hline & Submitting a draft social report to the company manager for review and approval \\
\hline & Evaluating the effectiveness of social reporting \\
\hline
\end{tabular}

Figure 1. Algorithm for Social Reporting by “Arterium” corporation

To form a qualitative social report, you must adhere to a number of principles. They will help to structure the implementation of accounting procedures and reporting. Among the main principles: systematic, scientific, autonomous, quantitative evaluation, materiality, hasty, efficiency, transparency, clarity, analyticity, independence, consistency and timeliness. All data must be documented.

The "Arterium" Social Report, in the first place, should satisfy the needs of the major groups of stakeholders. Social reporting should reflect the priorities of the enterprise. It is important to understand that the information displayed in the report should affect the decision-making of users by reporting, be essential. Thus, drawing up a social report requires consistent and clear action, which will be based on specific principles.

\section{CONCLUSIONS}

Social responsibility of business and corporate social responsibility are oriented towards responsible attitude towards business, product or service, consumers, employees, partners, environment, etc. Social responsibility pursues the goal of streamlining, harmonizing social relations and ensuring their progressive and stable development. The concept of CSR was considered on an example of the pharmaceutical company "Arterium". It was found that the 
Protsenko, V. and Oliinyk, O. (2019). "Increasing social responsibility in the management of industrial enterprises (using the example of "Arterium" corporation)", Management and entrepreneurship: trends of development, 3(09), pp. 52-65. DOI: https://doi.org/10.26661/2522-1566/2019-3/09-04

corporation, implementing the principles of social responsibility of business towards society, focuses on the following areas: business ethics and ethical marketing, innovation and product development, patient health and safety, protection against fraud, investment in employee training, environmental policy and Green office, support for health, sports and education programs, community care. To improve corporate social responsibility, an algorithm for creating a social report was proposed. According to our plan, the structure of the report involves the grouping of qualitative and quantitative indicators in terms of several sections in a randomized form. The disclosure of indicators in accordance with the structure will serve as the basis for the adoption of socio-economic decisions and future external social reporting.

\section{REFERENCES}

Antoshko, T., Krush, P. and Tyulenyeva, Y. (2013), Vprovadzhennya korporatyvnoyi sotsial'noyi vidpovidal'nosti na promyslovykh pidpryyemstvakh [Implementation of corporate social responsibility at industrial enterprises], NTUU „KPI”, Kyiv, Ukraine

Arterium Corporation (2013) "Corporate Social Responsibility Report for 2013", [Online], available at: http://www.arterium.ua/upload/files/reports/csr_report_2013_en.pdf (Accessed 12 May 2019).

Behma, Y., Vinnikov, O. And Red'ko, O. (2006), Yakisne doslidzhennya metodiv vprovadzhennya sotsial'noyi vidpovidal'nosti biznesu $v$ Ukrayini. [Qualitative research of methods of implementation of corporate social responsibility in Ukraine], Fakt, Kyiv, Ukraine

Bowen, H.R. (2013). Social Responsibilities of the Businessman. Available at: http://dx.doi.org/10.2307/j.ctt20q1w8f.

Bredgaard, T. (2004). "Corporate social responsibility between public policy and enterprise policy”, Transfer: European Review of Labour and Research, 10(3), pp.372-392. Available at: http://dx.doi.org/10.1177/102425890401000305.

Carroll, A. B. (1991), "The Pyramid of Corporate Social Responsibility: Toward the Moral Management of Organizational Stakeholders, Business Horizons", [Online], available at: http://bas.sagepub.com/cgi/content/refs/38/3/268 (Accessed 18 May 2019).

Davide, S. (2004), "Corporate Social Responsibility in Europe: Analyzing Business in Transnational Contexts Working paper", [Online], available at: http://eco.uninsubria.it (Accessed 19 May 2019).

Drucker, P.F. (1993). “The responsibility-based organization”, Post-Capitalist Society, pp.8899. Available at: http://dx.doi.org/10.1016/b978-0-7506-0921-0.50010-0.

Friedman, M. (1970). The Social Responsibility of Business Is to Increase Its Profits. Corporate Ethics and Corporate Governance, pp.173-178. Available at: http://dx.doi.org/10.1007/978-3-540-70818-6_14.

Garriga, E. Melé D. (2004), "Untangling the Jungle of Corporate Social Responsibility Theories", Journal of Business Ethics, vol. 53, pp. 51-71.

Hrishnova, O. (2010), "Social responsibility of business: essence, value, strategic directions of development in Ukraine", Ukrayina: aspekty pratsi, no. 7, pp. 3-8.

Hryshchuk, V. (2012) Sotsial'na vidpovidal'nist' [Social responsibility], Lviv, Ukraine.

Jones, B. (2013). Friedman, Milton. Encyclopedia of Corporate Social Responsibility, pp.1174-1175. Available at: http://dx.doi.org/10.1007/978-3-642-28036-8_466.

Jones, D.A., Willness, C.R., Madey, S. (2014), Why are job seekers attracted by corporate social performance? Experimental and field tests of three signal-based mechanisms. Acad. Manag. J. 57 383-404. 10.5465/amj.2011.0848

Kolot, A. (2018), "Corporate Social Responsibility: The Evolution and Development of Theoretical Views", [Online], available at: http:// kneu.edu.ua/. (Accessed 19 May 2019).

Lapteva, L.G. (2004), Sotsyal'naia otvetstvennost' byznesa. Korporatyvnaia otchetnost'. Novyj faktor vzaymodejstvyia byznesa y obschestva [Social responsibility of business. Corporate reporting. 
A new factor in the interaction of business and society], in Lapteva, L.G. (ed.), Delovoj jekspress, Moscow, Russia.

Matten, D., Moon, J. (2003), "Corporate social responsibility in Europe - state-of-the-art and future perspectives in a globalizing economy", [Online], available at: http://www.nottingham.ac.uk/nubs/ICCSR/news/conferencecontributions.html (Accessed 17 May 2019).

Moon, J. (2014). Corporate Social Responsibility: A Very Short Introduction. Available at: http://dx.doi.org/10.1093/actrade/9780199671816.001.0001.

Putten, F. (2005), "Research Agenda for International Corporate Social Responsibility”, $N R G$ working paper series, no. 05-09, [Online], available at: http://www.nyenrode.nl/download/NRG/workingpapers/NRG05-09.pdf. (Accessed 19 May 2019).

Robins, P. and Chentso, D. (2002), Osnovy menedzhmentu [Fundamentals of Management], Osnovy, Kyiv, Ukraine.

Russell, S. V., Evans, A., Fielding, K. S. and Hill, C. (2016), Turn it off: An action research study of top management influence on energy conservation in the workplace. Front. Psychol. 7:389 10.3389/fpsyg.2016.00389.

Seivwright, A.N. and Unsworth, K.L. (2016), Making sense of corporate social responsibility and work. Front. Psychol. 7:443 10.3389/fpsyg.2016.00443.

Shapoval, V. (2009), "Evaluating the effectiveness of social investment", [Online], available at: http://www.rusnauka.com/24_NTP_2009/Economics/ 50506.doc.htm (Accessed 17 May 2019).

Shen, J. and Benson, J. (2016), When CSR is a social norm: how socially responsible human resource management affects employee work behavior. J. Manag. 42 1723-1746. $10.1177 / 0149206314522300$.

Tkachenko, N. (2008), "Motivation of business social responsibility", Ekonomika. Menedzhment. Pidpryiemnytstvo, no. 19, pp. 102-109.

Wood D. J. and Jones R. E. (1995), Stakeholder mismatching: a theoretical problem in empirical research on corporate social performance. Int. J. Organ. Anal. 3 229-267. 10.1108/eb028831.

\section{СПИСОК ВИКОРИСТАНИХ ДЖЕРЕЛ}

Антошко Т., Круш П., Тюленєва Ю. Впровадження корпоративної соціальної відповідальності на промислових підприємствах: монографія. Київ: НТУУ „КПІ”, 2013. 275с.

Бегма Ю., Вінніков О., Редько О. Якісне дослідження методів впровадження соціальної відповідальності бізнесу в Україні. Київ : Факт. 2006. 326 с.

Грішнова О. Соціальна відповідальність бізнесу: сутність, значення, стратегічні напрями розвитку в Україні. Украӥна: аспекти праці. 2010. № 7. С. 3-8.

Грищук В. Соціальна відповідальність: навчальний посібник. Львів : Львівський державний університет внутрішніх справ, 2012. 152 с.

Звіт про корпоративну соціальну відповідальність за 2013 рік корпорації «Артеріум». URL : http://www.arterium.ua/upload/files/reports/csr_report_2013_en.pdf

Колот А. Корпоративна соціальна відповідальність: еволюція та розвиток теоретичних поглядів. URL : http:// kneu.edu.ua/.

Ткаченко Н. Мотивация социальной ответственности бизнеса. Н. Ткаченко. Економіка. Менеджммент. Підприємництвво. 2008. № 19. С. 102-109.

Социальная ответственность бизнеса. Корпоративная отчетность. Новый фактор взаимодействия бизнеса и общества: сб. ст., лекций и выступлений / под общ. ред. Л.Г. Лаптева. Москва : ЗАО Финансовый издательский дом «Деловой экспресс», 2004. 310 с.

Стефан П. Робінс, Девід А. Де Ченцо Основи менеджменту. Київ : Основи, 2002. 670 с. 
Protsenko, V. and Oliinyk, O. (2019). "Increasing social responsibility in the management of industrial enterprises (using the example of "Arterium" corporation)", Management and entrepreneurship: trends of development, 3(09), pp. 52-65. DOI: https://doi.org/10.26661/2522-1566/2019-3/09-04

Шаповал В. Оцінка ефективності соціальних інвестицій. URL : http://www.rusnauka.com/24_NTP_2009/Economics/50506.doc.htm.

Bowen, H.R. (2013). Social Responsibilities of the Businessman. Available at: http://dx.doi.org/10.2307/j.ctt20q1w8f.

Bredgaard, T. (2004). "Corporate social responsibility between public policy and enterprise policy”, Transfer: European Review of Labour and Research, 10(3), pp.372-392. Available at: http://dx.doi.org/10.1177/102425890401000305.

Carroll Archie B. The Pyramid of Corporate Social Responsibility: Toward the Moral Management of Organizational Stakeholders, Business Horizons, July-August 1991. URL :http://bas.sagepub.com/cgi/content/refs/38/3/268.

Davide Secchi Corporate Social Responsibility in Europe: Analyzing Business in Transnational Contexts Working paper, 2004/34. Department of Economic. Università degli Studi dell\&apos;Insubria URL : http://eco.uninsubria.it.

Dirk Matten, Jeremy Moon "Corporate social responsibility in Europe -state-of-the-art and future perspectives in a globalizing economy", at Academy of Management Annual Conference. August 2003.

Seattle

URL : http://www.nottingham.ac.uk/nubs/ICCSR/news/conferencecontributions.html

Drucker, P.F. (1993). "The responsibility-based organization”, Post-Capitalist Society, pp.8899. Available at: http://dx.doi.org/10.1016/b978-0-7506-0921-0.50010-0.

Elisabet Garriga, Domènec Melé Untangling the Jungle of Corporate Social Responsibility Theories. Journal of Business Ethics. 2004. №53. P. 51-71.

Frans Paul van der Putten A Research Agenda for International Corporate Social Responsibility. NRG working paper series November 2005 no. 05-09 URL : http://www.nyenrode.nl/download/NRG/workingpapers/NRG05-09.pdf.

Friedman, M. (1970). The Social Responsibility of Business Is to Increase Its Profits. Corporate Ethics and Corporate Governance, pp.173-178. Available at: http://dx.doi.org/10.1007/978-3-540-70818-6_14.

Jones D.A., Willness C.R., Madey S. (2014). Why are job seekers attracted by corporate social performance? Experimental and field tests of three signal-based mechanisms. Acad. Manag. J. 57 383-404. 10.5465/amj.2011.0848.

Jones, B. (2013). Friedman, Milton. Encyclopedia of Corporate Social Responsibility, pp.1174-1175. Available at: http://dx.doi.org/10.1007/978-3-642-28036-8_466.

Moon, J. (2014). Corporate Social Responsibility: A Very Short Introduction. Available at: http://dx.doi.org/10.1093/actrade/9780199671816.001.0001.

Russell S. V., Evans A., Fielding K. S., Hill C. (2016). Turn it off: An action research study of top management influence on energy conservation in the workplace. Front. Psychol. 7:389 10.3389/fpsyg.2016.00389.

Seivwright A.N., Unsworth K.L. (2016). Making sense of corporate social responsibility and work. Front. Psychol. 7:443 10.3389/fpsyg.2016.00443.

Shen J., Benson J. (2016). When CSR is a social norm: how socially responsible human resource management affects employee work behavior. J. Manag. 42 1723-1746. 10.1177/0149206314522300.

Wood D. J., Jones R. E. (1995). Stakeholder mismatching: a theoretical problem in empirical research on corporate social performance. Int. J. Organ. Anal. 3 229-267. 10.1108/eb028831. 


\section{ПІДВИЩЕННЯ СОЦАЛЬНОЇ ВІДПОВІДАЛЬНОСТІ В МЕНЕДЖМЕНТІ ВИРОБНИЧИХ ПІДПРИЕМСТВ (НА ПРИКЛАДІ КОРПОРАЦЇ̈ “АРТЕРІУМ”)}

\author{
Проценко Владислав Олегович \\ Запорізький начіональний університет \\ Запоріжжя, Україна
}

\author{
Олійник Олександр Миколайович \\ Запорізький начіональний університет \\ Запоріжжя, Украӥна
}

У роботі розглянуто теоретичні основи корпоративної соціальної відповідальності, проаналізовано зарубіжні і вітчизняні практики, зокрема на основі корпорації «Артеріум». Актуальність роботи полягає у дослідженні сучасного стану корпоративної соціальної відповідальності в Україні, й, зокрема, на підприємстві «Артеріум». Все більше компаній запроваджують КСВ у свою діяльність, стандарти для бізнесу змінюються і соціально відповідальна поведінка стає обов'язковим елементом успішного підприємництва. Метою дослідження $€$ виявлення методів підвищення соціальної відповідальності в сучасному менеджменті виробничих підприємств на прикладі корпорації «Артеріум». В ході дослідження було встановлено, що корпорація, реалізуючи принципи соціальної відповідальності бізнесу перед суспільством, зосереджується на таких напрямках: ділова етика та етичний маркетинг, інновації та розвиток продукції, здоров'я та безпека пацієнтів, захист від шахрайства, інвестиції в навчання працівників, політика захисту навколишнього середовища та дотримання принципу «екологічний офіс», підтримка програм охорони здоров'я, спорту та освіти, громадський догляд.

Для досягнення поставленої мети були вирішені наступні завдання:

- досліджено сутність поняття корпоративної соціальної відповідальності та стан КСВ у світі;

- проаналізована діяльність корпорації «Артеріум»;

- оцінено стан корпоративної соціальної відповідальності в Україні;

- вивчено досвід іноземних компаній у зазначеній сфері.

За результатами проведеного дослідження:

- обгрунтовано ситуацію та ефективність корпоративної соціальної відповідальності на зазначеному підприємстві;

- запропоновано алгоритм розробки соціального звіту для корпорації «Артеріум» як метод підвищення соціальної відповідальності.

Ключові слова: корпоративна соціальна відповідальність, соціальна звітність, соціальний контроль, соціальні інвестиції.

\section{ПОВЫШЕНИЕ СОЦИАЛЬНОЙ ОТВЕТСТВЕННОСТИ В МЕНЕДЖМЕНТЕ ПРОИЗВОДСТВЕННЫХ ПРЕДПРИЯТИЙ (НА ПРИМЕРЕ КОРПОРАЦИИ “АРТЕРИУМ”)}

\author{
Проценко Владислав Олегович \\ Запорожский национальный университет \\ Запорожье, Украина
}

\author{
Олейник Александр Николаевич \\ Запорожский национальный университет \\ Запорожье, Украина
}

В работе рассмотрены теоретические основы корпоративной социальной ответственности, проанализированы зарубежные и отечественные практики, в частности на основе корпорации «Артериум». Актуальность работы заключается в исследовании современного состояния корпоративной социальной ответственности в Украине и, в частности, на предприятии «Артериум». Все больше компаний вводят КСО в свою деятельность, стандарты для бизнеса меняются и социально ответственное поведение становится обязательным элементом успешного предпринимательства. Целью исследования является выявление методов повышения социальной ответственности в современном 
Protsenko, V. and Oliinyk, O. (2019). "Increasing social responsibility in the management of industrial enterprises (using the example of "Arterium" corporation)", Management and entrepreneurship: trends of development, 3(09), pp. 52-65. DOI: https://doi.org/10.26661/2522-1566/2019-3/09-04

менеджменте производственных предприятий на примере корпорации «Артериум». В ходе исследования было установлено, что корпорация, реализуя принципы социальной ответственности бизнеса перед обществом, сосредотачивается на следующих направлениях: деловая этика и этический маркетинг, инновации и развитие продукции, здоровье и безопасность пациентов, защита от мошенничества, инвестиции в обучение работников, политика защиты окружающей среды и соблюдение принципа «экологический офис», поддержка программ здравоохранения, спорта и образования, общинный уход.

Для достижения поставленной цели были решены следующие задачи:

- исследована суть понятия корпоративной социальной ответственности и состояние КСО в мире;

- проанализирована деятельность корпорации «Артериум»;

- оценено состояние корпоративной социальной ответственности в Украине;

- изучен опыт иностранных компаний в указанной сфере.

По результатам проведенного исследования:

- обоснованно ситуацию и эффективность корпоративной социальной ответственности на указанном предприятии;

- предложен алгоритм разработки социального отчета для корпорации «Артериум» как метод повышения социальной ответственности.

Ключевые слова: корпоративная социальная ответственность, социальная отчетность, социальный контроль, социальные инвестиции. 